\title{
乗用車の自動変速機用遊星歯車変速機の騒音・振動に関する研究*
}

\author{
陳勇*1，石 橋彰*2 \\ 園 田計二*2, 松 原 正 已*3
}

\section{Studies on Noise and Vibration of Planetary Gear Drives for Automatic Transmission of Passenger Cars}

\author{
Yong CHEN*4, Akira ISHIBASHI, \\ Keiji SONODA and Masami MATUBARA \\ *4 JATCO Corporation, 700-1, Aza-Kamoda, Imaizumi, Fuji City, Shizuoka, 417-8585 Japan
}

\begin{abstract}
Noise levels of motor vehicles are becoming an important subject of environment regulation. Recently, a reduction in the noise and vibration of planetary gear drives to be used for an automatic transmission of passenger cars has become an important project. The authors designed and made a planetary gear testing machine which can test the component planetary gear trains in an automatic transmission of the cars. The phase difference in gear tooth meshing is given to the planet gears which make contact with the sun and internal gears. As component gears, shaved and hardened helical gears with and without grinding were used and the rotational speed and the tooth load were changed. The experimental results clearly showed that a reduction in running noise and vibration was surely obtained when the phase difference in tooth meshing was introduced.
\end{abstract}

Key Words: Gear, Machine Element, Planetary Gear, Automatic Transmission, Gear Noise, Vibration

\section{1. 緒言}

近年，自動変速機を装着した乗用車の飛躍的な普及 とともに，自動車の快適性を左右する要因の一つとし て車室内の静萧性への要求がますます高まる中で, 歯 車騷音に対する要求も一段と厳しくなってきている. 自動変速機の低騒音化の要求から, 遊星歯車の騒音低 減が重要な課題となっている. 自動変速機の変速機部 を構成する遊星蒾車機構に扔いて, 歯車のかみあいに よって発生するギヤノイズは，低車速から高車速の広 い運転条件で発生するが, 此較的軽負荷の場合に問題 となることが多い.これまで行われている自動車用自 動変速機の遊星歯車機構の動的性能に関する研究は少 ない(1)(2).また，実際に自動変速機用遊星歯車機構だ けの騒音と振動を分離して実験的に検討した研究はほ とんどない.

本研究では, 遊星蒾車のかみあい回転周期の観点か ら遊星歯車のかみあい位相差と遊星歯車のねじり振動

\footnotetext{
*原稿受付 1999 年 4 月 1 日.

*1 正員, JATCO (株) (雨 417-8585 富士市今泉字鴨田 700-1).

*2 正員, 熊本工業大学機械工学科 (承860-0082 熊本市池田 4 22-1).

*3 JATCO(株)

E-mail : yuu_chin@jatco.co.jp
}

の関係を求め, 位相差を与えた遊星歯車機構と位相差 を与えない遊星歯車機構を用いて, 歯車の仕上げ法, かみあい率などを変えて, 種々の運転条件において, 遊星歯車機構の騒音と振動加速度を測定し, 比較考察 を行った.

2. かみあい位相差とねじり振動に 関する考察

$2 \cdot 1$ 遊星歯車機構のねじり振動 遊星歯車穖構 の振動を考察する場合は，回転方向で変動する力(ね じり振動)とラジアルカ向に変動する力(曲げ振動)を 考光る必要がある。数個の遊星歯車はキャリヤ上に同 じピッチで配置するのが一般である，遊星歯車の歯数 とキャリヤ上の各遊星歯車の配置によって, 各遊星歯 車の歯が同時にかみあいを始めるか，あるいは異なる 時期にかみあい始めるかが決まる，従来の遊星歯車の 歯数設定は，設計も容易となることから，ラジアル方 向変動力が釣合うように設定されていたように推定で きる、すなわち各遊星歯車の歯が同時にかみあいを始 めるようになっている．実車の車室内騷音の測定結果 より, 自動変速機用遊星歯車機構の歯車対のかみあい 起振力はおもに回転方向のねじり振動の影響と考えら れる(2).ただし，一般には自動変速機用遊星蒌車機構 
の内歯車のリム厚は薄く, リムとしてのたわみが大き いため, 内歯車と遊星歯車間の歯のかみあい起振力は, 太陽歯車と遊星歯車間のかみあい起振力に比べて, 相 対的に小さい(3).太陽歯車と各遊星歯車の間には，同 じような性質の動荷重を生ずるが，歯のかみあいに位 相差のある場合には, 各かみあい起振力は, 各遊星歯 車のかみあいを始める時期の差だけずれている。

図 1 は遊星歯車機構の太陽歯車と遊星歯車のかみあ い位相差の概念図を示す。遊星雪車 (1)の歯元と太陽 歯車の歯先がかみあい始めたとき(図 1 の $\left.Q_{1}\right)$, 遊星 歯車 (2)の歯元と太陽歯車の歯先がかみあい始める点 $Q_{2}$ において，かみあい位相差がないと仮定する。し たがって遊星歯車 (2) との実際のかみあい位置 $Q_{3}$ 点 から位相差なしの $Q_{2}$ 点位置までの太陽歯車の転がり 角 $\Delta \theta$ がかみあい位相差角度となる。

ここでは太陽㐘車の歯数を遊星歯車の個数 $n$ で割 ったときの余りを $Z^{\prime} と す る と, ~ j$ 番めの遊星歯車の 歯が太陽歯車の歯とかみあいを始めるときの位相差 $\Delta \theta$ はかみあい周波数成分の $k$ 次の項に対し式(1)で 示される。

$$
\Delta \theta=k j\left(2 \pi Z^{\prime} / n\right)
$$

各遊星歯車の歯がかみあい始めてから終わるまでの 動荷重の変動の経過が完全に等しいと仮定して $j$ 番 めの遊星歯車とかみあって太陽歯車に加わるかみあい 起振力を $k$ 次の項に関する正弦波で表すと次式のよ うになる(1)(4).

$$
F_{k j}=F_{n k j} \sin k\left[\omega t+j\left(2 \pi Z^{\prime} / n\right)\right]
$$

ただし， $F_{n k j}$ は振幅である。したがって各遊星歯車か ら太陽歯車に加わる $k$ 次の動荷重に基づくモーメン トは，歯の 1 ピッチを周期とする単純な正弦波状の変

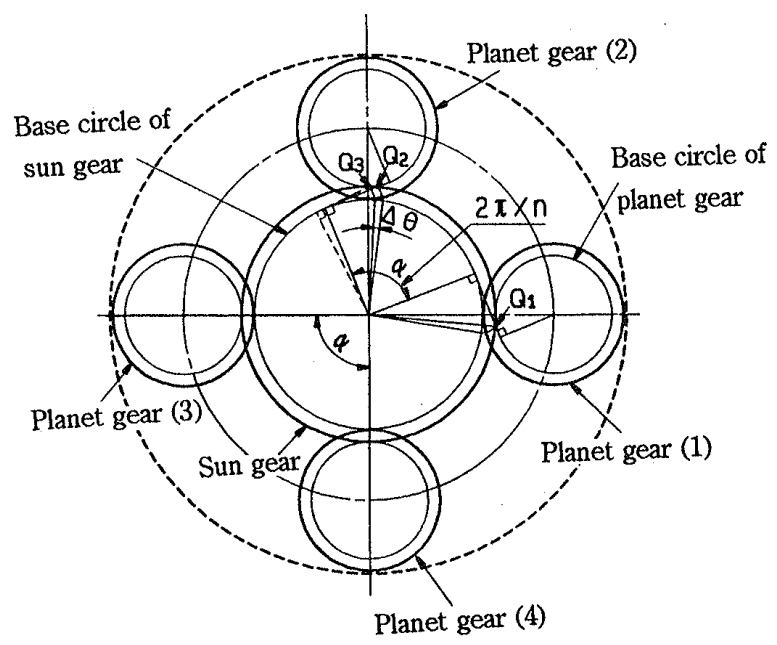

Fig. 1 Schematic drawing of meshing phase difference in planetary gear drives with four planet gears
化成分で，かつその振幅が等しいならば，次式で示さ 机る。

$$
\begin{aligned}
& \sum M_{k}=\sum_{j=1}^{n} F_{k j} R_{o} \cos \alpha_{n} \\
& \quad=F_{n k} R_{o} \cos \alpha_{n} \sum_{j=1}^{n} \sin k\left[\omega t+j\left(2 \pi Z^{\prime} / n\right)\right]
\end{aligned}
$$

ただし， $F_{k j}$ : 遊星歯車かみあい起振力, $R_{0}$ : 太陽歯 車のピッチ円半径, $\alpha_{n}$ ：歯直角圧力角, $k$ : かみあい 周波数成分次数である。一般に $\left(k \cdot Z_{A} / n\right)$ が整数でな い場合は $\sum M_{k}=0$ となる。ただし， $Z_{A}$ は太陽歯車の 歯数である.

$2 \cdot 2$ 遊星歯車機構の位相差設計 遊星歯車機構 において太陽歯車の歯数と遊星歯車の配置角の選択に よって各遊星歯車と同時にかみあう複数の歯のかみあ い関係の位相が異なるようにすることができる。これ は, 遊星歯車の個数 $n$ に関連して, 各歯車の歯数を適 当に選択することである。かみあい位相差設計をする 場合には，遊星歯車対の歯数設定条件は次式で示され る。

$$
\begin{aligned}
& \left(Z_{C}+Z_{A}\right) / n=m \\
& Z_{A} / n \neq m
\end{aligned}
$$

ここに, $Z_{A}$ は太陽歯車の歯数, $Z_{C}$ は内柬車の蒾数, $n$ は遊星歯車の個数, $m$ は整数である.

これより遊星歯車を等間隔に配置しても，各遊星歯 車と太陽歯車のかみあい位置に $1 / n$ ピッチのかみあ い位相差をもたせることができる。式(4)と（5)の条 件に彷って歯数を選択すれば, 太陽歯車と遊星歯車, 遊星歯車と内歯車のおの打ののかみあいにおいて，か みあい位相が異なるようになる。したがって，かみあ い周期に基づく振動の一つの要因となる回転方向での かみあいによる回転変動は，歯対の総合ばねこわさの 変動成分が同位相で互いにずれて完全に釣合うので， 理論上は零となる(2).このため, 遊星蒾車と太陽歯車 がかみあうときに回転方向の振動を著しく減少させる と考えられる.

図 2 はかみあい位相差の作用をわかりやすく説明す るために，本研究において位相差を付けた遊星歯車機

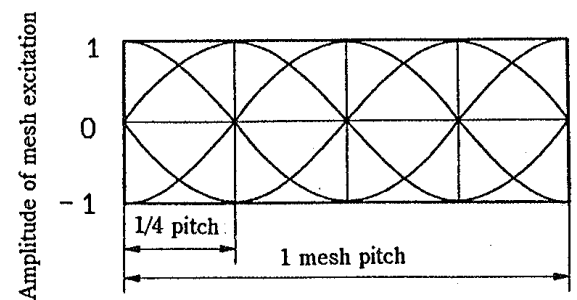

Fig. 2 Elimination of exciting forces caused by four planet gears 
構にお汀る起振力の变化を示す．各遊星歯車から加わ るかみあい起振力は歯の 1 ピッチを周期として単純な 正弦状に変化すると仮定した成分で，また各遊星歯車 間での振幅と周期が同じとした場合であるので，かみ あい位相差によって起振力が完全に相殺されるようす を示している。また，鈴木らの式(5)を利用して遊星歯 車の個数を 3 または 4 にした場合, 位相差のある遊星 歯車機構と位相差のない遊星歯車機構の回転伝達誤差 を計算した，遊星歯車の個数が 3 個の場合でも 4 個の 場合でも，位相差を与えれば，回転伝達誤差は 30 分の 1 以下に小さくなっている(計算結果の詳細は省略). 遊星歯車の個数が振動と騒音に及焙す影響は位相差設 計の影響よりもかなり小さいと考光られる。

\section{3． 実験装置と実験方法}

$3 \cdot 1$ 遊星歯車試験機 図 3 は, 本研究において, 実用されている乗用車の自動変速機の遊星歯車機構を 各変速段の騒音と振動が個別に測定できるように設 計, 試作した遊星歯車試験機の軸断面図を示す. 固定 部や連結部には内スプライン継手を設けているので, 負荷トルクが作用すれば，連結部などが均等にかみあ う位置に動き，負荷が均等に作用するようになってい

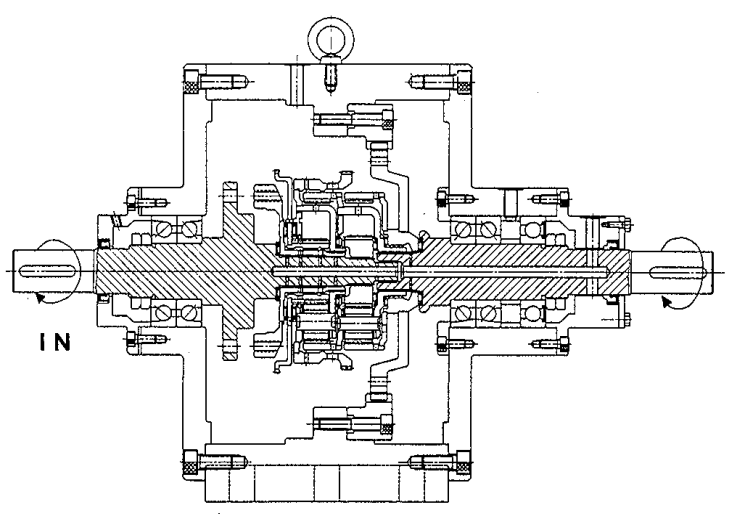

Fig. 3 Axial section of planetary gear testing machine

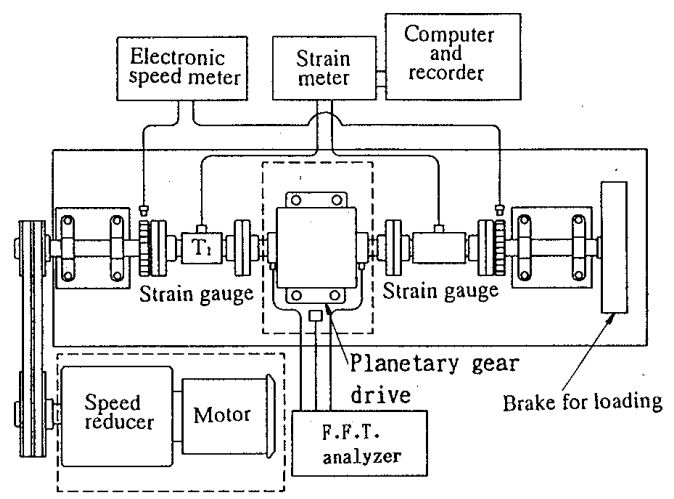

Fig. 4 Test stand for planetary gear drive
る. 固定部や自動変速機用遊星歯車変速機構の各変速 段を別々に試験できるようになっている。この試験機 では, 遊星歯車列の連結の仕方, 基本軸の固定の仕方, 歯車の駆動と従動の入れ替えなどによって, 実用され ている乗用車のように変速比を 4 種類変えることがで きる。

$3 \cdot 2$ 実験装置 実験に使用した動力吸収式歯車 負荷実験装置の測定機器など配置の概略を図 4 亿示 す. 負荷運転中における回転数と入力軸と出力軸の卜 ルクは，電子式回転計とひずみゲージで測定する。ま た，図 4 の破線で示すように駆動モー夕，無段変速機， 遊星歯車試験機を防音箱で覆った。これによって暗騒 音が約 $6 \mathrm{~dB}$ 下った。

$3 \cdot 3$ 試験歯車 実験に用いた遊星歯車の諸元は 表 1 に示す。太陽菌車扔よび遊星歯車はシェービング 加工後浸炭焼入れ処理のみをしたものと, 焼入後 MAAG 歯車研削盤で研削したものを用いた。前者の 精度は JIS 3〜4 級, 歯面粗さは最大高さ粗さで約 6 $\mu \mathrm{m}(R y)$ である. 研削した蒾車の精度は JIS $0 \sim 1$ 級, 歯面粗さは最大高さで約 $2 \mu \mathrm{m}$ である。また, 表 1 に 示すように，正面かみあい率を変えるために歯先円直 径の異なる遊星歯車と太陽歯車を 2 種類使用した。“実 験に用いた試験歯車対は量産歯車の同じ製造ロットの ものを使用して各歯の歯面形状ができるだけ一様にな るようにした。全部の試験歯車の歯形, 歯筋の精度お よび遊星歯車を組付用キャリヤの遊星歯車シャフト穴 位置精度と配置精度などを測定して実験条件が同じに なるように注意した。

$3 \cdot 4$ 実験方法 上記の 2 種類の歯形かみあい率 と異なる加工法で仕上げた遊星歯車, 太陽歯車をそれ ぞれ遊星歯車試験機に組付け, 潤滑油温度は $32 \pm 2^{\circ} \mathrm{C}$ になるように設定して運転した。潤滑油は流量を 1.5 $l / \min て ゙$, 油ポンプによる循環給油である。用いた潤 滑油快実用されている自動変速機用油である. 入力卜 ルクは0〜80 N-mo範囲とし, 入力軸回転数は 500 2 $400 \mathrm{rpm}$ の範囲内で, $100 \mathrm{rpm}$ ずつ変化させて 遊星歯車機構の振動加速度と騒音を測定した. 2 個の 加速度ピックアップを出力軸および入力軸を支持する

Table 1 Specifications of gears used for planetary gear trains

\begin{tabular}{|c|c|c|c|c|c|c|}
\hline & \multicolumn{3}{|c|}{ Planetary gear train I } & \multicolumn{3}{|c|}{ Planetary gear train II } \\
\hline & Sun & Planet & Internal & Sun & Planet & Internal \\
\hline Number of teeth & 33 & 21 & 75 & 37 & 19 & 75 \\
\hline Normal module & \multicolumn{3}{|c|}{1.23} & \multicolumn{3}{|c|}{1.23} \\
\hline Normal pressure angle $\left({ }^{\circ}\right)$ & \multicolumn{3}{|c|}{$20^{\circ}$} & \multicolumn{3}{|c|}{$20^{\circ}$} \\
\hline Number of planet pinion & \multicolumn{3}{|c|}{3} & \multicolumn{3}{|c|}{4} \\
\hline Hel ix angle & \multicolumn{3}{|c|}{$23.3^{\circ}$} & \multicolumn{3}{|c|}{$23.3^{\circ}$} \\
\hline Profile contact ratio (A) & 1.6 & & 1.84 & & 65 & 1.81 \\
\hline Profile contact ratio (B) & 1.3 & & 1.69 & & 30 & 1.66 \\
\hline
\end{tabular}


軸受の近傍に取付けた。騒音計は防音箱に国われた遊 星歯車試験機上面より $60 \mathrm{~mm}$ の位置に固定して, A 特性で測定した。

\section{4. 実験結果および考察}

4 •1 振動・騒音に及ぼす位相差の影響 図 5 と 6 は歯車接線荷重を $200 \mathrm{~N}$ とした場合における遊星歯 車機構の振動・騒音に及ぼす位相差の影響を示す。試 験歯車以高歯遊星歯車車対 [表 1 の Profile contact

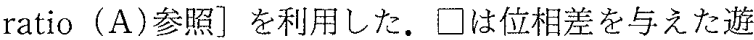
星歯車機構 (II)，、泣㑑差のない配置の遊星歯車機 構 ( I ) を用いた場合の騒音・振動の変化を示す。図に 示すように位相差のある遊星歯車機構は，位相差のな い遊星歯車機構より騒音レベルが $3 \sim 7 \mathrm{~dB}$ ，振動レベ

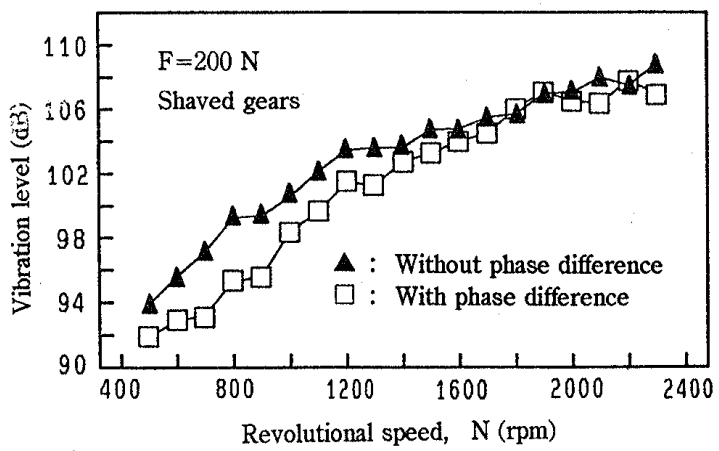

Fig. 5 Effect of mesh phase difference on vibration

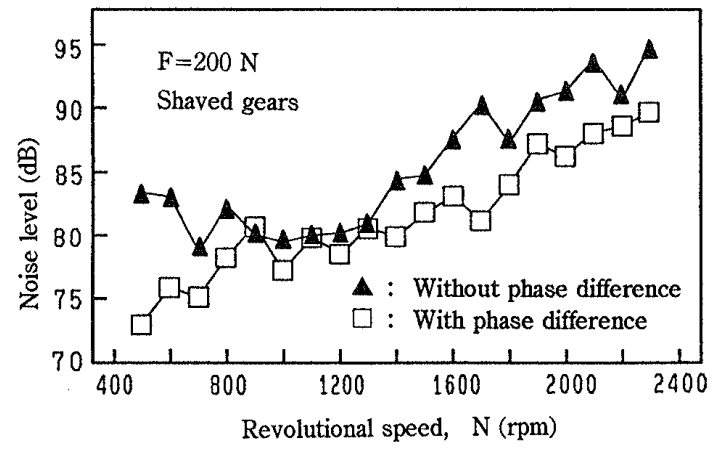

Fig. 6 Effect of mesh phase difference on noise

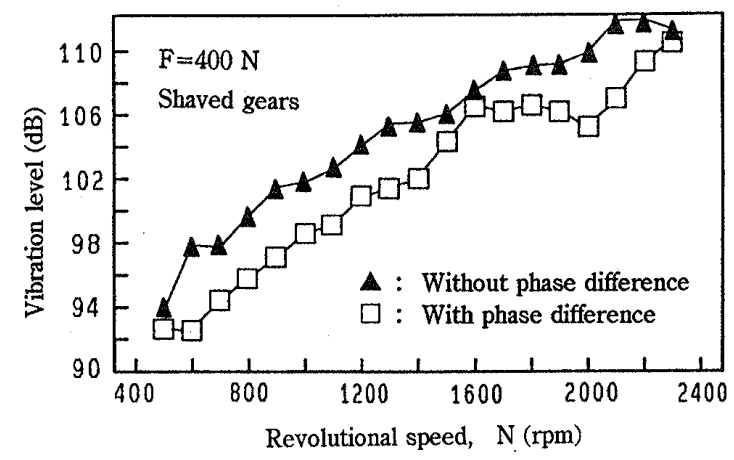

Fig. 7 Effect of mesh phase difference on vibration
ル2〜4 dBだけ低くなっている.図 7 と 8 は上記と 同じ試験歯車を用いた場合において歯車接線荷重を $400 \mathrm{~N}$ とした場合の振動・騒音の測定結果である。接 線荷重 $200 \mathrm{~N}$ の場合の測定結果と比較すれば, 曲線の 傾きはほぼ司じであるが, 負荷トルクの増加に伴って 位相差の影響がさらに明りょうになっている。これ は，負荷が大きくなると歯のたわみが大きくなり，相 対的に歯形誤差の影響が小さくなるためと考えられ る.

図 9 と 10 は, 試験遊星歯車機構の遊星歯車と太陽 歯車をMAAG 歯車研削盤で研削した歯車を用いた場 合の振動・騒音測定結果である。ほほ全測定回転数の 範囲において，位相差をもつ遊星歯車機構は位相差な しの遊星歯車機構よりも騒音レベルが $6 \sim 9 \mathrm{~dB}$ だ

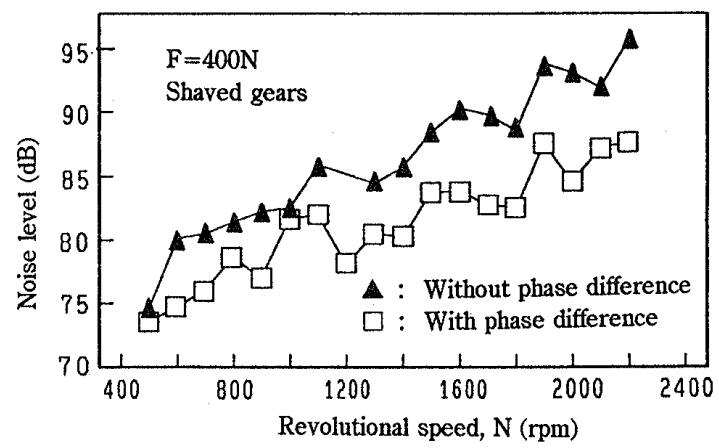

Fig. 8 Effect of mesh phase difference on noise

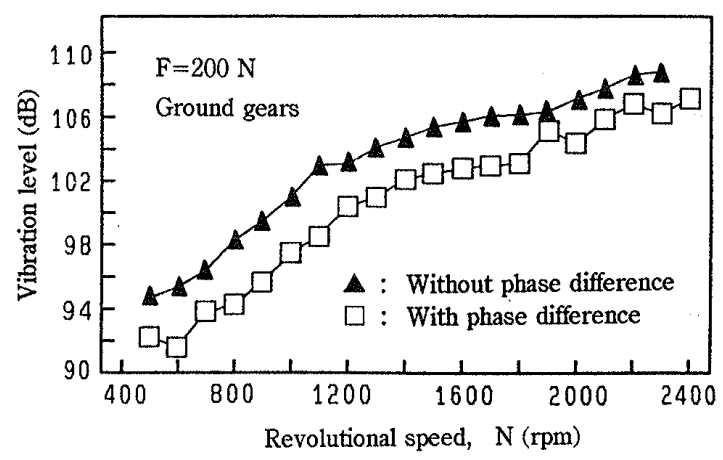

Fig, 9 Effect of mesh phase difference on vibration

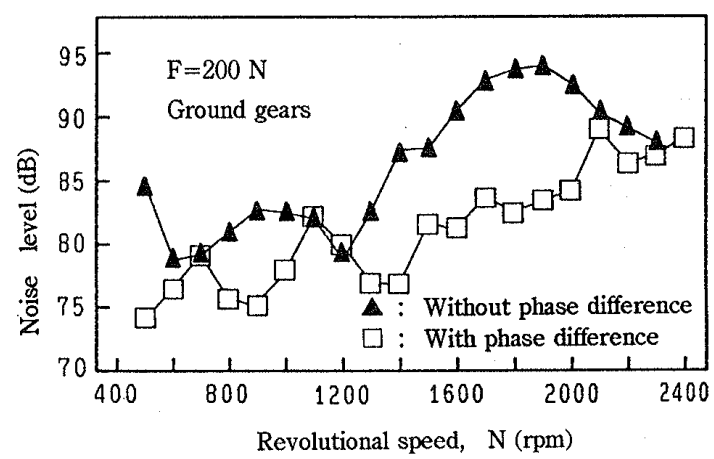

Fig. 10 Effect of mesh phase difference on noise 


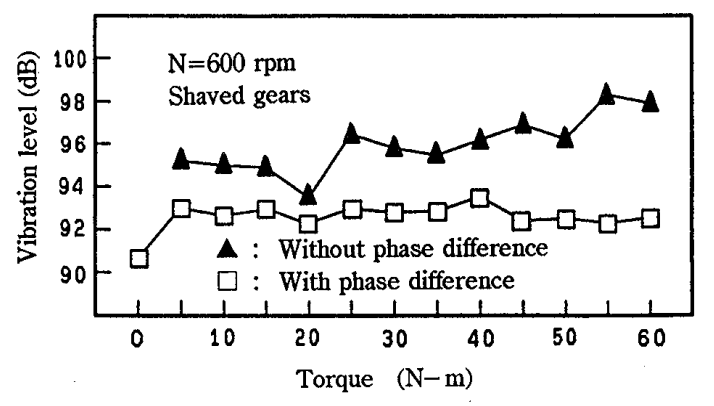

Fig. 11 Effect of mesh phase difference on vibration

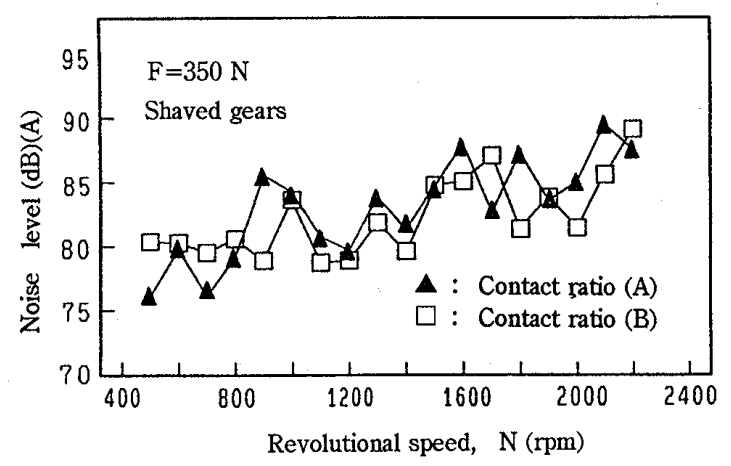

Fig. 12 Effect of mesh phase difference on noise

低い. また，振動レベルも 3〜 $4 \mathrm{~dB}$ 程度低くなってい ることを示している，研削した歯車を用いたため歯車 精度の影響が相対的に少なくなり，位相差の効果がな お一層明らかになったものと考光られる。図 11 は負 荷トルクの変化が振動に及ぼす影響を示す，低トルク から高トルク負荷領域まで位相差のある遊星歯車機構 の振動レベルは負荷トルクの変化に対して鈍感であ る. 位相崖なしの遊星歯車機構はトルクが増加すれ ば, 振動が 3〜 $4 \mathrm{~dB}$ 程度増加することを示している。

$4 \cdot 2$ 振動・騒音に及ぼす歯形かみあい率, 精度の 影響 図 12 は位相差をもつ遊星歯車機構において 正面かみあい率の大きな遊星歯車対 [表 1 の Profile contact ratio（A) 参照]と正面かみあい率の小さい 歯車詨 [表 1 の Profile contact ratio（B)］を使用し た場合の騒音レベルである，正面かみあい率の異なる 遊星歯車機構 (高歯と並歯)の振動・騷音レベルには差 ははっきり表れていない。これは，かみあい率が異な ると，かみあいの歯のばねこわさの変化の周期が異な るためである，位相差をもつ遊星歯車機構は，歯車対 のばねこわさの変化によって現れるかみあい起振力の 変化が打ち消されるため, 高歯にすることによってか みあい率を大きくしてもギヤノイズレベルへの影響が 少なくなっているものと考えられる.

図 13 は位相差のある遊星歯車機構の振動に及ぼす 試験歯車精度の影響を示す。太陽歯車および遊星歯車

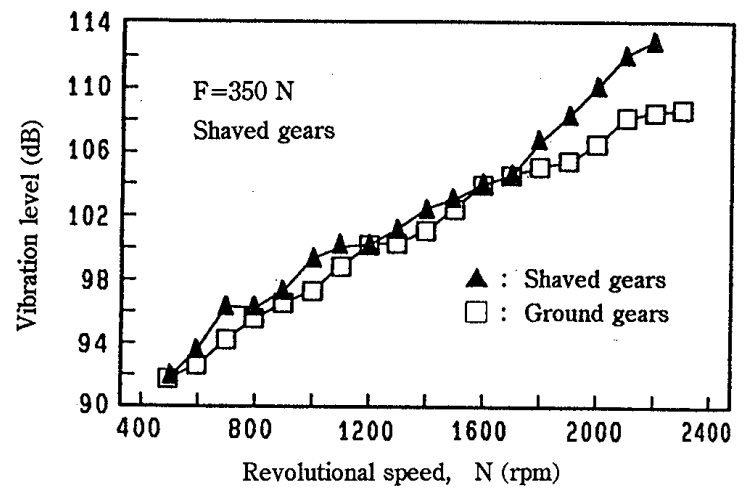

Fig. 13 Effect of grinding on vibration

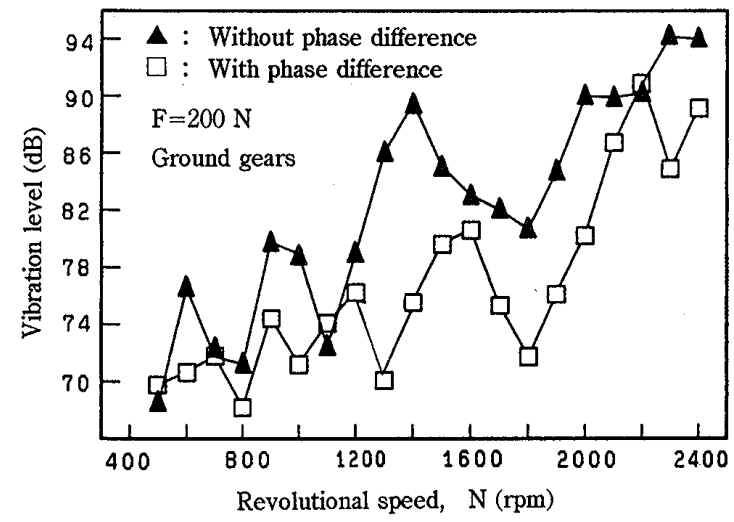

Fig. 14 Effect of first mesh frequency of mesh phase difference on vibration

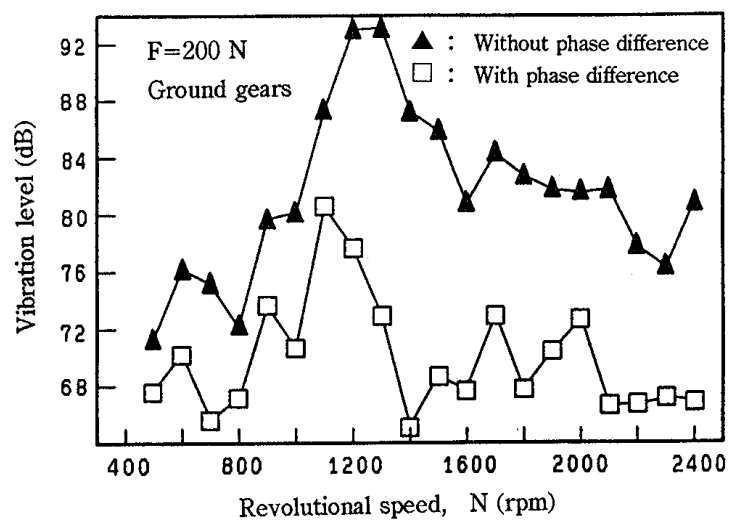

Fig. 15 Effect of second mesh frequency of mesh phase difference on vibration

はシェービング仕上げ後, 浸炭焼入れのまま使用した 場合と浸炭焼入れ後歯面を研削して使用した場合の振 動レベルの測定結果を示している，歯面を研削した歯 車を用いた遊星歯車機構は振動レベルが 1 〜 dB だ け低い.これは, 歯車の加工精度の向上と菊面粗さの 減少のためと考えられる。特に回転数が高い場合 (1800 rpm 以上)にはこの傾向が強く表れるようであ 尚.

$4 \cdot 3$ 振動に及ぼす回転次数の影響＼cjkstart高速フーリ 

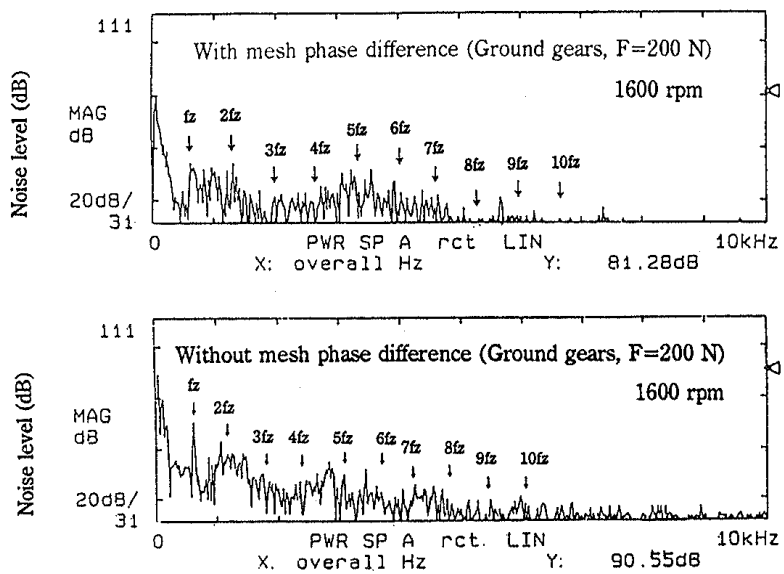

Fig. 16 Noise spectrum of planetary gear drive

エ変換分析器(FFT)を用いて振動数成分を測定した. 図 14 と 15 は測定された振動の中の 1 次と 2 次かみあ い成分に及ぼす位相差の影響を示す。遊星歯車機構の 動荷重の変動成分の中で, 振幅の最も大きいものは一 般に 1 次であるが(4), 乗用車用自動変速機の遊星ギヤ ノイズでは, 車室内の静萧性(騒音振動性能)に対して おもな影響を及ぼすものはかみあいの1次と 2 次の振 動成分であると考元られる。本実験では位相差のある 遊星歯車機構の 1 次と 2 次の振動レベルはかなり低く なっている(図 14，15)。すなわち，位相差設計でかみ あいの一次と二次成分を小さくできることが実験的に 明らかにでさたと思う。

$4 \cdot 4$ 振動加速度と騒音の周波数分析 図 16 と 17 は，かみあいに位相差を与えた遊星歯車機構と位相 差を与えない遊星歯車機構に扔いて，歯面を研削した 太陽歯車と遊星歯車を用いて運転した場合の騒音レ心゙ ルと振動加速度の周波数成分を示す，位相差なしの遊 星歯車機構は, 騒音レベルと振動加速度レベルが約 3 9 dB だけ高い. 遊星蒾車のかみあい周波数 $F_{z}$ の 1〜3 次の成分を示す山の高さも位相差のある遊星歯 車機構よりも大きく，高周波数領域にも周波数成分の あることがわかる。これは位相差のある遊星歯車機構 の場合，各遊星歯車が太陽歯車とかみあうとき，それ ぞれ歯のかみあいの位相がずれる構成となるため，苗 対のかみあい状態の変化に伴う歯のばねこわさの変化 などから誘起されるねじり振動のかみあい位相がずれ て合成されるので干渉効果で騒音や振動が弱められた
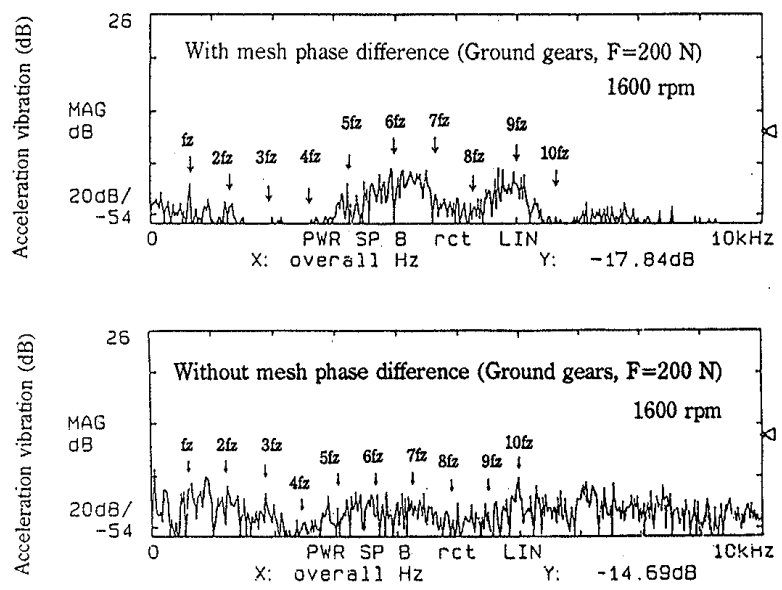

Fig. 17 Acceleration spectrum of planetary gear drive

ものと考えられる。

5. 結 論

実用されている乗用車の自動変速機 (4 段変速) に使 用されている遊星歯車変速機の各変速段の遊星歯車機 構を別々に試験できる遊星歯車試験機を独自に設計製 作して，試験椟車の仕上げ法，かみあい率などを変え， 回転数や歯面荷重を変化させて実験を行い, 次の結果 を得た。

（1）遊星歯車のかみあいに位相差を与えれば，遊 星歯車機構の振動と騒音が小さくなることを明らかに した.

（2）歯のかみあいに位相差を与えれば遊星歯車機 構の騒音・振動がかみあい率の影響を受けにくくなる ことを明らかにした。

（3）汃あい位相差を与えた遊星歯車機構は，歯 車の精度および歯面粗さを向上させることによって騒 音と振動をさらに小さくできることを明らかにした。

\section{文献}

(1) Palmer, W.E., ほか 1名, SAE Paper, (1977), No. 770561.

(2) Katoh, T., ほか 2 名, Proc. MPT '91, (1991), 530.

（3）森川邦彦・丸山昇，日産技報，第 31 号 (1992-6)，85,

（4）仙波正荘, 歯車, 第 10 巻 (1967)，3637, 日刊工業新聞社.

（5）鈴木義友・清野慧 - ほ 33 名, 自動車技術会学術講演会 前刷集, No. 862 (1986), 523 . 